\title{
Business Models as Drivers of the Low Carbon Power System Transition: A Multi-Level Perspective
} Martin E. Wainstein ${ }^{1 *}$, Adam G. Bumpus ${ }^{2}$

* corresponding author: martin.wainstein@climate-energy-college.org

1- Australian-German Climate \& Energy College. School of Earth Sciences. The University of Melbourne, Australia

2 - School of Geography, Faculty of Science. The University of Melbourne, Australia; Visiting Scholar, Bill Lane Center for the American West, Stanford University.

\begin{abstract}
Decarbonising the power system holds a critical role in climate change mitigation. Recent developments in technology are helping change the current centralized paradigm into integrated distributed clean energy resources. In spite of these developments, radical transformation is not occurring at a speed to effectively meet environmental targets, mostly due to the incumbent carbon lock-in trajectory. We argue, therefore, that business model (BM) innovation dynamics are key drivers in accelerating the low carbon power system transition, often operating irrespective of the underlying technology. We combine BM theory with the multi-level perspective on sociotechnical transitions to present a useful framework to analyze this potential transition. This paper presents the application of this framework characterizing relevant BM dynamics of niche and regime business actors, and supporting these with illustrative examples. Particularly, we find that new actors of the distributed energy business are achieving market scale by offering financially innovative BM that do not require upfront costs from customers. Higher penetrations of renewable energy sources in liberalized electricity markets are destabilizing the historical BM of large centralized utilities through erosion of wholesale prices. Furthermore, a shift towards distributed and dynamic energy resources further challenges incumbents and might bring opportunities for BMs focused on active customer participation and social value creation. As these tendencies are expected to accelerate, we find analyses of BMs will have important relevance for future power system transition research.
\end{abstract}

\section{Introduction}

The electrical power system holds a central role in meeting emission targets for climate change mitigation. In order to keep mean temperature rise within $1.5-2^{\circ} \mathrm{C}$ relative to pre-industrial levels, as suggested by the IPCC and restated in the 2015 UNFCCC Paris Agreement (IPCC, 2013; UNFCCC, 2015), feasible energy transformation pathways [developed with Integrative Assessment Models] require significant reduction in energy intensity (i.e. efficiency), a radical electrification of the energy system, and a fast decarbonisation of the electricity sector (Kriegler et al., 2014; Rogelj et al., 2015). But considering that electricity corresponds to just $18 \%$ of total energy consumption, and $67 \%$ of its primary source is fossil based (IEA, 2014), this scenario requires a challenging technological and systemic revolution in this sector. This shift is not occurring at the speed required: wide scale renewable energy technologies and carbon-saving innovations have faced significant resistance when attempting system-wide diffusion (Bumpus et al., 2014; Geels, 2014). Resistance comes from a complex structure of actors mostly centered around fossil fuel incumbent firms that have been locked into sustaining carbon intensive business models (BMs)(Dangerman and Schellnhuber, 2013; Unruh, 2000).

Recent increases in electricity prices, reduction in renewable technology manufacturing costs, and government clean energy incentives, are, however, producing opportunities for cleantech entrepreneurs and new BMs (Frankel et al., 2014; Huijben and Verbong, 2013). The result is yielding increased incorporation of distributed energy resources (DER) such as photovoltaics, smart meters, stationary batteries and electric vehicles. DERs are helping change the essential paradigm in the electricity sector of industrialized nations, evolving from a traditional value chain to a more complex participatory network (Klose et al., 2010). This tendency is expected to further accelerate in coming years (Frei, 2008; Schleicher-Tappeser, 2012). Furthermore, since conventional utility BMs were not designed to tap the most value from distributed renewable generation, they are a current locus of destabilization and thus experimentation, innovation and emerging opportunities (eLAB, 2013; Richter, 2012; Schoettl and Lehmann-Ortega, 2011b).

The dynamics in the transition between old and new power system business models involves tensions between incumbent and new business actors, a centralized versus a distributed technological paradigm, and a societal shift from a passive to an active user role in its value chain. Some industrialized nations with an ongoing energy transition are showing early signs worth noticing. Large incumbent utilities are forced to reconfigure their BM (Jeevan Vasagar, 2015; Richter, 2013a) whilst new distributed energy corporations are achieving financial scale with competitive BMs (Biello, 2014; Hess, 2013). In parallel, modern markets are hosting BMs with increased customer participation, both through collective value creation through peer-to-peer (P2P) platforms (Andersson, 2013; Belk, 2014), and through socially active initiatives such as grassroots innovations and for-benefit firms (Hess, 2013; Seyfang et al., 2014). Collectively, these dynamics may present windows of opportunities to destabilize the rigid foundations of the current carbon lock-in and accelerate the inertia towards a low carbon power system. This paper discusses the relevance of these systemic signals by considering BMs as a critical unit of analysis, and provides specific illustrative examples for a qualitative characterization of these emerging tendencies.

This article adopts a sociotechnical framework for its analysis. It recognizes the transformation required in the power sector does not only involve a change in technology, but at a system level shift in elements such as user practices, regulations, industrial networks, markets and infrastructure (Geels, 2002; Verbong and Geels, 2010). Specifically, the multi-level perspective (MLP) on sociotechnical transitions has been a useful approach to understand 
the changes and tensions at different societal levels, including those between new and incumbent actors and innovations, which give rise to new technological systems (Grin et al., 2010). However, the specific role BMs have on these interactions has largely been left out of the literature (Geels, 2011). This is surprising given BMs are 'value creation engines' (Zott et al., 2011), devices for competitive advantage, both for incumbents ensuring their locked-in trajectory, and for new actors commercializing new technologies in novel ways. We highlight here how BMs, rather than commercialized technology per se, can become disruptive niche innovations.

We perform an analysis combining BM theory and the MLP to better understand critical business dynamics in the current landscape of modern power systems. We illustrate our observations by focusing on BM dynamics in illustrative examples of niche and regime business actors. With this work, we seek to address whether BM tensions and innovative $\mathrm{BM}$ initiatives are acting as disruptive forces on the barriers of the low carbon transition. We also intend to contribute to an emerging literature linking BM and sociotechnical transitions (Bidmon and Knab, 2014; Huijben and Verbong, 2013; Loorbach and Wijsman, 2013; Tongur and Engwall, 2014). The paper is structured as follows: section 2 provides the background literature, theoretical framework and relevance, section 3 presents a characterization of tendencies in the power system transition using the BM and MLP framework, section 4 provides the illustrative examples to further elaborate on these tendencies, and section 5 concludes and discusses further research.

\section{Background \& Approach}

\subsection{Methodological approach}

We undertake a qualitative analysis to answer our research questions. Firstly we review of the literature to bring business model theory and the multilevel perspective together (Boons and Lüdeke-Freund, 2013; Geels, 2011). Then we undertake a qualitative analysis of three examples of how this theoretical development is played out in reality. Given the complexity of energy systems and the emerging nature of DERs, these are not representative case studies, but rather illustrative examples to highlight the principles put forward in the paper (Suddaby, 2006). These examples were chosen based on the criteria that the jurisdictions (Germany and California) they exist in are leading examples of how energy systems are evolving, and where new business models for energy are being tested (Bumpus et al., 2014). As a result, they are not intended to elucidate a general pattern but instead to describe how business models and the MLP are interconnected through three specific dynamics of energy transition (cf. Halinen and Törnroos, 2005). We undertook a comprehensive analysis multiple online resources (industry reports and news platforms, company's websites, reports

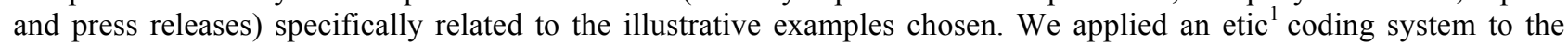
data, highlighted key themes for analysis based on the 9-point business model deconstruction and MLP components, and evaluated the illustrative examples against our theoretical proposition.

\subsection{Actor Dynamics in the Energy Transition Lock-In: A Multi Level Perspective}

The MLP has been a popular framework to understand how major sociotechnical shifts occur, and how they can be influenced towards a sustainable pathway (Geels, 2012). It argues these changes occur through dynamic and non-linear interactions between: niches, sociotechnical regimes (a structure of practices and rules formed by multiple actors such as industry, policy, culture and science), and the sociotechnical landscape (the wider context of societal changes) (Geels, 2002; Kemp et al., 1998).

Niches are described as protected pockets where experimentation occurs, yielding innovations that become the seeds for socio-technical transitions. The system in to which those niche-innovations are inserted - known as the sociotechnical regime - is, however, characterized by resilience and lock-in based on specific technological, social and cultural systems. This system, therefore, poses resistance to innovations attempting to diffuse into a wider societal context (Geels, 2004). A technological transition, then, implies a radical reconfiguration of a sociotechnical regime through the incorporation of certain niche-innovations. These shifts often depend on the pressure that the sociotechnical landscape can put on the regime in order to destabilize and open it for change. The sociotechnical landscape has least flexibility given its material character (e.g. spatial arrangement of cities and infrastructures) and long established practices such as financial markets and geopolitics. However, it can suffer shocks that provide windows of opportunities for reconfigurations in the niche-regime dynamics. Figure 1a shows a representation of the nested hierarchy nature of these three societal levels (Geels, 2002).

The MLP framework has been particularly useful to understand energy transition dynamics (Elzen et al., 2002; Verbong and Geels, 2007; Verbong and Geels, 2010). Many of the alignments causing the fossil fuel or carbon lock-in are the same, or similar, to those addressed in the general concept of a sociotechnical regime, where a technological trajectory escalates into synergic mutual dependencies among the technological system, the firms involved, the industrial complex, professional associations, government and policy makers reinforcing the initial technological trajectory (Geels, 2005). The particular rigidity of the current energy regime is subsequently intensified due to its extensive scale and central role in today's society (Urry, 2014). Unruh (2000) has described this regime as a 'TechnoInstitutional Complex' with its growth and resilience explained by perpetual returns to scale. Geels (2014) illustrates

\footnotetext{
${ }^{1}$ Etic codes can provide a fine resolution in categorizing events, and draw out the 'dimensions' to a given statement, allowing the meaning of each to be compared against apparently similar ones to pick out the more subtle differences (Crang, 2005).
} 
how firms employ 'corporate political strategies' to influence and lobby government to then collectively apply forms of power favoring incumbent actors and resisting change. Dangerman and Schellnhuber (2013) identify the limited shareholder liability in energy and finance corporations as being the critical firm-level factor behind this rigid trajectory. They argue that the absence of shareholder liability in firms blocks feedback from the environmental system (i.e. affected by climate change), making the conventional system less likely to adopt an alternative path.

Arguably, the MLP and carbon lock-in literature exposes the central role that the private sector has in sustaining the current energy regime. In fact, its resilient trajectory can be interpreted as a lock-in at the BM level, where corporations ensure shareholder profit by maintaining economies of scale of the fossil fuel complex and apply multiple strategies to minimize market risk (Dangerman and Schellnhuber, 2013).

The incumbent energy regime is challenged by niche-innovations, represented by clean energy technologies and energy saving practices. But from a market perspective, these innovations require BMs that can effectively commercialize them, drive their objective value and compete with the incumbent system. The sociotechnical landscape can exert pressure on the regime allowing diffusion of these innovations and the rise of new corporate actors. Oil price volatility $^{2}$ and an international movement to address climate change and energy security, are few examples of such pressures shifting market conditions (Shackley and Green, 2007). As a result, niche-regime dynamics are mostly analyzed around opposing technologies, business actors with competing interests, and rules and practices favoring certain adoptions (Geels, 2014). Given the importance of activities of niche actors (especially companies) in disrupting the regime, we introduce BMs as key loci of focus to further characterize these multi-level interactions in the context of the energy transition.

\subsection{Business Model Theory}

Although BMs have been integral to trading and economic activity since the outset of business, only relatively recently have they been considered as an emerging unit of analysis and thus object of scholarly studies (Chesbrough and Rosenbloom, 2002). The exact definition of a BM is still fragmented within the academic literature, with some theoretical framework developments from eBusiness, strategy and innovation research (Zott et al., 2011). More recently, however, a growing body of articles incorporate BMs into sustainability studies and processes (Boons and Lüdeke-Freund, 2013; Boons et al., 2013).

In spite of this fragmented state, a logical definition of the BM is to describe it as a "market device" that outlines the rationale of how an organization creates, delivers and captures value (Osterwalder and Pigneur, 2010; Zott and Amit, 2010). As opposed to a business strategy, which is a set of dynamic activities centered on the competitive environment, the $\mathrm{BM}$ is a static design of the configuration of elements and activity characteristics tailored to maximize an opportunity with organizational effectiveness (George and Bock, 2011). As a model with heuristic logic, its overarching elements can be broken down into: i) the value proposition, describing what is the value in the product or service offered by a firm; ii) the value creation, explaining how value is actually developed and delivered by the firm; and iii) the value capture, which relates to the financial system employed to turn that value into economic profit (Baden-Fuller and Morgan, 2010; Chesbrough and Rosenbloom, 2002; Osterwalder, 2004).

A higher resolution map of the BM is particularly useful for empirical analysis. Osterwalder 9-point decomposition of the BM provides greater clarity of the components involved in the value creation process (Osterwalder et al., 2005). This framework is useful because companies actually engage in boundary-spanning activities, and operate within complex partnership networks in both upstream and downstream supply-chain processes (Osterwalder and Pigneur, 2010). Figure $1 \mathrm{~b}$ shows an adaptation of the 9-point BM components, which includes a visual clarification of how the three elements of value proposition, value creation and value capture, as well as the upstream and downstream processes, encompass and connect the different 9 components.

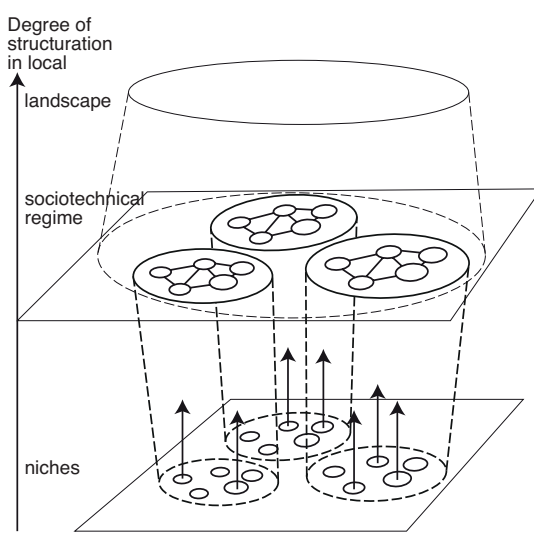

Figure 1a. Nested hierarchy of the three societal levels in the Multi Level Perspective. Adapted from Geels (2002).

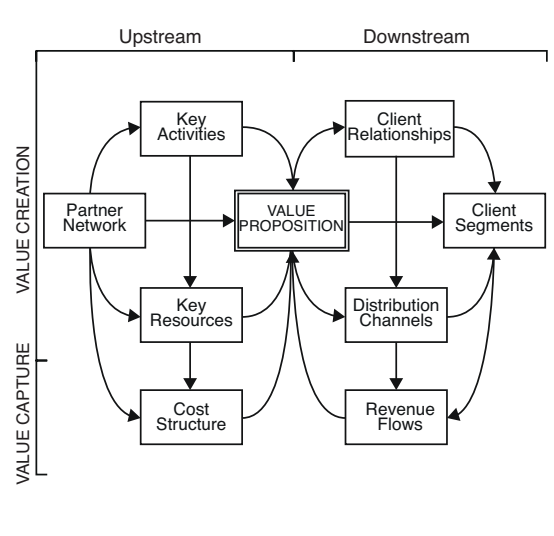

Figure 1b. Osterwalder 9-point decomposition of the Business Model. Adapted from Osterwalder (2005).

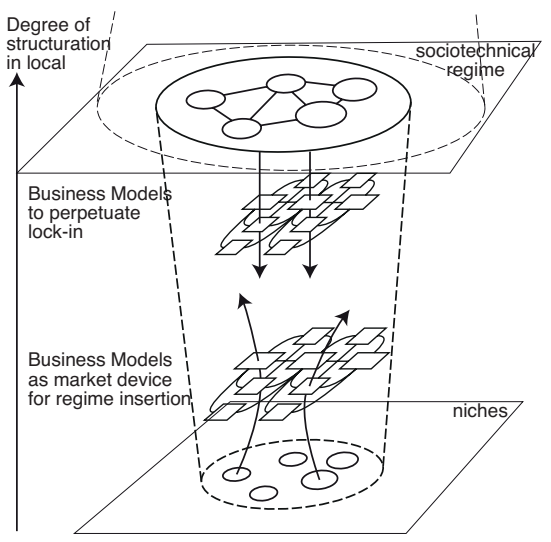

Figure 1c. Business Models in the MultiLevel Perspective. BM as critical drivers of sociotechnical transitions acting as market vehicles for niche and regime actors. Author illustration based on sources for Fig. 1a and

${ }^{2}$ We do not undertake an analysis of oil price volatility here, but follow two assumptions: one, thłbultimately oil price will rise and/or become volatile enough that it is economically disadvantaged as a stable source of energy, and two, that policy movements to reduce emissions from fossil fuel use will be the norm (cf. Murray and King, 2012). 
BMs provide a vehicle for technologies and innovations to insert in the market and successfully unlock their value (Chesbrough and Rosenbloom, 2002). Yet since Christensen's original theory of disruptive innovations (1997), which focused mostly on technology, BM innovation has been increasingly recognized as a major source of market disruption, irrespective of the underlying product (Chesbrough, 2010; Teece, 2010). In essence, an innovative BM redefines the relationship between a product and the customer by fundamentally shifting the value proposition of the existing business. As such, BM innovation often enlarges the market by attracting new customers that find the new value proposition more appealing (Markides, 2006). Incumbent BMs often struggle to incorporate this form of innovation since it involves a reconfiguration of the conventional value creation process (Charitou and Markides, 2012; Christensen and Raynor, 2003).

Larger societal processes can also influence innovative reconfigurations of the BM. For example, the global financial crisis in 2008 acted as a landscape shock affecting consumer's buying power. Unintentionally, this fostered an increase of two forms of BM innovation. On one hand, it shifted the conventional American consumption and ownership paradigm, accelerating the now called "sharing," P2P or "collaborative economy" (Belk, 2014). This societal process has already produced disruptive firms that, through innovative BMs, reimagined the value chain of stagnant businesses such as hoteling or taxi services. P2P Internet platforms are now growing as the stage for alternative commerce, where consumers and their idle resources become the essential component of the value creation process (Andersson, 2013). On the other hand, along with public corporate scandals, the financial crisis exposed shortcomings of the conventional for-profit BM to many consumers (Mickels, 2009). Particularly in the U.S., this increased the demand for alternative ethical BMs, leading to a growing legislation of the 'benefit corporation' (and other similar legal variations) as legal corporate entities (Esposito, 2012; Murray, 2012).

These tendencies, by example, draw further attention to BM theory as a way to understand structural disruption and its link with larger societal processes. This paper combines Osterwalder's 9-point decomposition of the BM, as a heuristic system map, with the MLP on sociotechnical transitions, another heuristic map of the overarching dynamic environment in which companies and innovations operate. We outline next why this is vital in understanding the low carbon transition within the power sector.

\subsection{Business Models and the Low carbon Transition}

Given that low carbon energy solutions are generally provided by private sector companies aiming to derive (and drive) value from the market, BMs are, therefore, an essential analytical component of understanding the low carbon socio-technical transition (Bidmon and Knab, 2014).

There are three main factors that make BM highly relevant in the low carbon transition. First, BMs are market devices for innovations to have competitive advantage (Chesbrough and Rosenbloom, 2002), to be widely adopted, and to become part of a sociotechnical regime. In fact, two different BMs could insert a same innovation into a market, targeting a same customer group, and have different results: one could make the innovation thrive, and the other wither (Markides and Charitou, 2004; Morris et al., 2005). Second, one of the potential sources of value creation attributed to a BM is lock-in (Amit and Zott, 2001). Lock-in is the metaphor to describe actors within a sociotechnical regime that gain from perpetuating an existing technology at the expense of a new one, blocking incoming innovations (Evans, 2011). BMs, and their ability to respond, create and capture value through innovation, are therefore an essential framework to understand the firm-level dynamics of the current fossil fuel lock-in, as well as the business aspects that can lead technological innovations towards a new lock-in (Bumpus, 2014; Zerriffi, 2007). Third, the BM is an essential locus of meaningful innovations in relation to the low carbon transition (Chesbrough, 2007; Loorbach and Wijsman, 2013). Perhaps the two most relevant streams are those that present a reconfiguration of social processes and those that incorporate sustainability as essential business components.

The extent and nature of the social web of a firm with external parties (i.e. other firms, institutions, government, customers etc.), is a critical component of the value creation process. So a reformulation of this external actor network, can lead to paradigm shifts along with increased competitive advantage. Product-Service Systems, for example, introduce a change in the relationship of a firm with its customer, from a one-time sale of a product to a continuous service provision (Ceschin, 2013). These systems also redefine needs for technology ownership as well as introduce alternative financial schemes (Gelbmann and Hammerl, 2014; Tongur and Engwall, 2014). On the other hand, BMs with higher collaboration and participation of actors in their value chain can be commercially beneficial whilst produce a decentralization of processes with higher resilience (Miles et al., 2006). P2P Internet platforms are good examples of how conventional customers becomes active participants, both by introducing their own resources to the market place, as well as in engaging in commercial activities (Belk, 2014). Processes of joint value creation between a network of actors are also meaningful to accelerate the maturity of innovations, as in the case of collaborative entrepreneurship or open innovations, where innovative ideas come from multiple sources outside the firm's boundaries (Chesbrough and Appleyard, 2007; Ribeiro-Soriano and Urbano, 2009).

BM innovation can also provide improved sustainability performance to both a firm and its specific technology (Lovins et al., 1999). If sustainability is considered in the value proposition, creation and capture processes, then BMs can be sustainable innovations themselves (Boons et al., 2013; Keskin et al., 2013). A critical requirement for a sustainable BM is a clear recognition of the environment and society as extended stakeholders of the firm's activities, embedding a triple bottom line (society, environment and economy) to ensure this is met in the business mechanisms, which can fall in a range of archetypes, and their effective outcomes (Bocken et al., 2014). Finally a more radical approach to sustainable BM innovation is seen in market-based approaches for social value creation addressing a specific social problem. Here, BMs become the tool employed in social innovation to achieve a social agenda in the 
most effective way. Establishing a clear definition and typology of social businesses and how they fit within social innovation is still an outstanding issue within academic literature (Dees, 2003; Weerawardena and Mort, 2006; Wilson and Post, 2013; Yunus et al., 2010). A general description is a business employed to address a social problem where the value created accrues more for society as a whole rather than for private individual, as defined by Phills at al. (2008). In the context of sustainability transitions, this niche is especially significant since it challenges not only how business practices are done in the sociotechnical regime, but also on the fundamental value proposition for why firms exist within society in the first place.

By considering BM theory in conjunction with the MLP, and the role of low carbon innovations, these relationships can be graphically depicted as shown in Figure 1c. Low carbon technologies are ultimately required to diffuse in mainstream markets, governed by the dynamics of the sociotechnical regime, but encountering a mismatch with the existing infrastructure, policy regulations, as well as the incumbents' fossil-based BMs, which employ political economic resistance to sustain their technological lock-in. However, the low carbon technology can have a competitive advantage if it uses a more innovative BM as a market device. Arguably, a sustainable BM could unlock further sustainability value considering society and the environment as extended stakeholder, or even radically challenge the conventional business practice through socially innovative business model where social value accrues more than shareholder value. These are important potential dynamics for the current power system in the context of low carbon innovations.

\section{The ongoing power system transition}

This section provides a background analysis on the systemic changes occurring in the power sector, and then uses the framework established in the previous section to characterize the role BM dynamics are having in this ongoing process.

\subsection{Changes in the Power System Paradigm}

The electricity grid was designed as a unidirectional system that delivers energy from centralized thermal power plants to customers through transmission and distribution lines. The liberalization of most electricity markets introduced competition of players along the supply chain with the aim to promote efficiency and drive costs down (Sioshansi, 2006). These markets generally function with a central operator that receives available generation capacities and dispatches them in order to meet demand in a reliable way. The dispatch is performed according to the generator's bidding price, from lowest to highest in a uniform clearing price auction, and where the price of the last generator dispatched sets the market wholesale price (i.e. the "spot" price). This system is called, among other names, the "Merit Order Dispatch" since it benefits the generators with the lowest bidding price, which tends to be its marginal cost (see Fig. 5 of section 4.3 for a conceptual illustration of the merit order dispatch). But, given electricity demand fluctuates from day to day, within a day, and inter-seasonally, and since generation must instantaneously match consumption, a common feature of liberal electricity markets is a highly volatile spot price. Unless they have pre-established contracts, generators revenues depend on wholesale prices. Utilities with retail service normally procure energy at these wholesale prices, add transmission and distribution costs, regulation costs, their own profit margins, and bundle this into a final flat retail price for consumers.

This standard electricity system faces challenges when it incorporates a high share of variable renewable generation sources such as wind and solar, as opposed to non-variable sources (i.e. hydro, geothermal and biomass). On one hand, it affects controllability and reliability of supply and demand dynamics, which can further increase the volatility of wholesale prices (Aghaei and Alizadeh, 2013). They can often supply energy to the market at moments where demand is low (i.e. decreasing prices) and fail to supply when demand is high (i.e. increasing prices). On the other hand, these

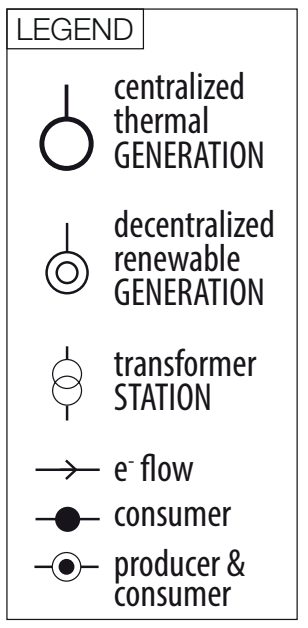

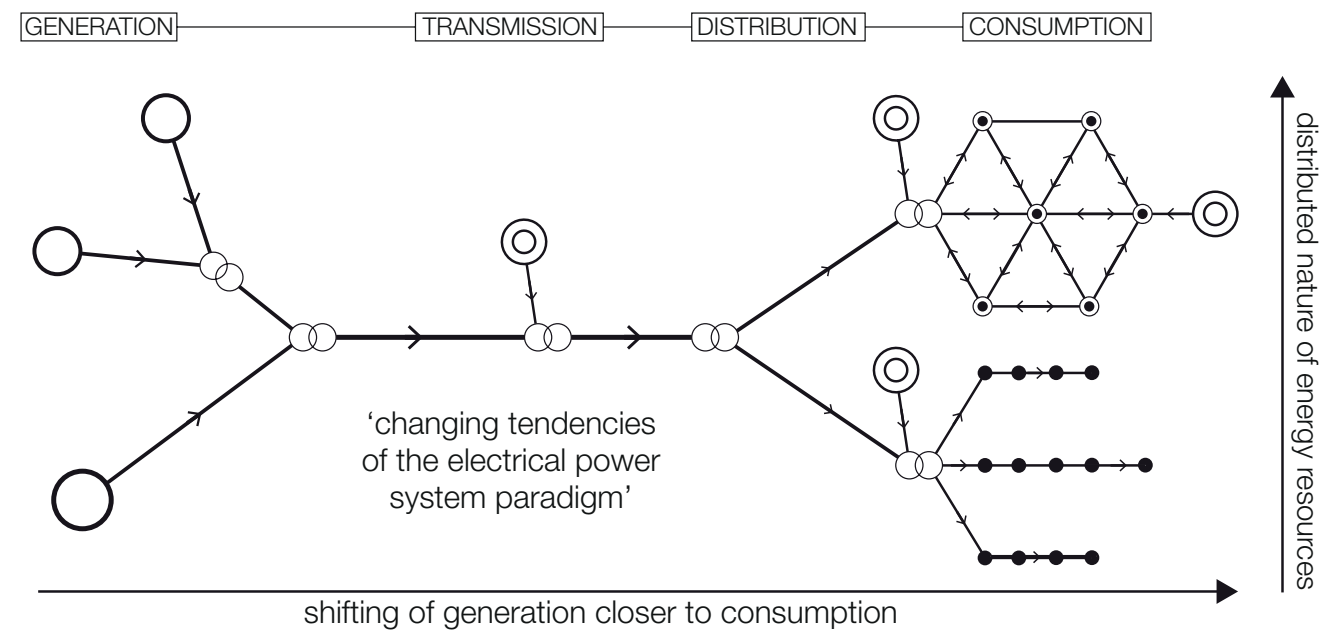

Figure 2. Tendencies shifting the power system paradigm. Heuristic representation of two generic tendencies observed in developed electrical power systems. Own illustration based on findings cited in section 3.1.

sources present the need for several structural changes considering they often have a more decentralized and distributed nature; feeding generation into low and medium voltage and increasing the number of low and medium capacity 
generators (i.e. 0-10MW) (O'Connell et al., 2014). Furthermore, a high share of renewable technology, having the lowest marginal cost in electricity market, ultimately drive wholesale prices down in a process called the "Merit-Order Effect" (McConnell et al., 2013; Ray, 2010).

As mentioned in the introduction, significant reductions in manufacturing costs and clean energy incentives have increased the incorporation of distributed energy resources (DERs). These include photovoltaic panels (PV) but also smart metering devices; demand-side management devices, which include stationary batteries as well as smart appliances with dynamic loads, such as heat pumps and thermostats; and, more recently, electric vehicles. Among other features, DERs are considered valuable assets to successfully deploy demand response programs. These programs employ several schemes for consumers to adapt to system conditions by altering consumption patterns. They are meaningful for the energy transition for at least two reasons (Strbac, 2008). First, along with large-scale electricity storage, demand response programs are proposed solutions to overcome supply-demand mismatch from renewable variability by adapting withdrawal profiles to generation fluctuations. Second, the coordination of DER in such programs is shown to markedly reduce peak demand events that can produce local network constraints. Overall, they also provide better tools for customers to maximize the value of their distributed assets (Siano, 2014).

Figure 2 shows a heuristic representation of two generic tendencies observed in developed electrical power systems: generation is increasingly shifted closer to consumption, and energy resources are deployed in a distributed manner, eventually changing the strict one-way flow of electrons to a two-way dynamic nature. These developments are significantly changing the BM paradigm in the electricity sector. This has produced a tension between BMs that deploy distributed energy resources and maximize their value, currently acting as an emerging niche, and the conventional utilities BM, which lack the framework to tap the most value out of them and therefore resists this change (eLAB, 2013; Ipakchi and Albuyeh, 2009).

\subsection{Characterization of Business Models in the Power Sector using a Multi-Level Perspective}

Recent reviews on utilities' BM, with specific focus on renewable energies, have classified them into essentially two generic branches: utility-side BM, and customer-side BM (Richter, 2012; Wüstenhagen and Boehnke, 2008). Whereas the utility-side BM is the classical bulk generation of electricity fed into the grid and sold as a regular commodity, the customer-side BM is a more comprehensive energy solution service provider, with higher level of interactions at the distribution edge of the network. The latter can be represented as an emerging niche, and is where most BM innovations occur, mostly by non-utility actors seizing the window of opportunity. The left side of Fig. 3 shows a visual representation of these generic BM relative to the power system supply-chain paradigm and within an MLP context.

The landscape influence of pressing climate change escalated in international policy agendas, and lead governments to develop environmental regulations promoting the incorporation of low carbon technologies throughout electricity networks. These range from feed-in-tariffs, renewable portfolio standards, to several forms of subsidies and tax incentives. Business actors are the main drivers of these benefits, allotted along the entire cleantech value chain. A sociotechnical study on distributed solar energy in the U.S.A., divides actors as "localism" grass-root developments and "third-party" for-profit companies; neither being conventional utility firms (Hess, 2013). This distinction is also useful to characterize actor groups in emerging customer-side BMs.

While grass-root initiatives are increasingly popular, it's the third-party actors that have attracted large pools of capital and know-how from the technology and finance industry, and proving to have the most market success thanks to innovative BMs (Hess, 2013). A prime example of this BM innovation is that of distributed solar Power Purchase Agreements (PPA) with third party financing. In a PPA, a household or commercial owner signs a long term agreement to purchase solar energy at an agreed competitive rate from a private firm, which subsequently installs the PV systems at the customer's premise and maintains ownership of the equipment throughout the term. Since customers are not required to incur in any upfront costs, this model has successfully targeted the large U.S. middle-income customer segment previously untapped (Salkin, 2012). These BM developments do not only encompass the solar industry. Other innovative BM applied by third party actors relate to financing DERs for households through product-service systems, such as with energy service companies (ESCOs) that fund energy saving technology and receive a percentage of the monetary savings (Ceschin, 2013). These are particularly useful to empower customers with valuable assets for demand response programs (i.e. smart DERs) without making them face upfront capital costs (Geelen et al., 2013). Other examples include the rapid reduction in the cost of stationary batteries, and roll out of demand response schemes, which are also producing a suite of innovative customer-side BMs (He et al., 2011). A prime example includes Californiabased Sunverge, which installs stationary batteries and aggregates them, along with other DER, into a Virtual Power Plants in order to more effectively trade electricity on the grid and reduce peak demand events (John, 2014; Schneider, 2015).

On the other hand, an emerging body of literature analyzing the role of community energy as grassroots innovations, in the context of the sociotechnical energy transition, is not finding similar encouraging results for this specific niche (Hargreaves et al., 2013; Hess, 2013; Ornetzeder and Rohracher, 2013; Seyfang and Haxeltine, 2012; Seyfang et al., 2014). A common finding relates to the internal and external challenges that grassroots developments have when trying to survive in the conventional market, with growth and replication towards wider adoption remaining as an even harder challenge. A recent study of community energy projects in the UK applies 'Strategic Niche Management' theory to evaluate their extent as a truly potential niche (Seyfang et al., 2014). Their findings observe that these initiatives lack commercial power. Although normally equipped with significant human capital, consolidating financial capital in order to scale and successfully compete against other corporate players is hardly a trait of grassroots developments. 


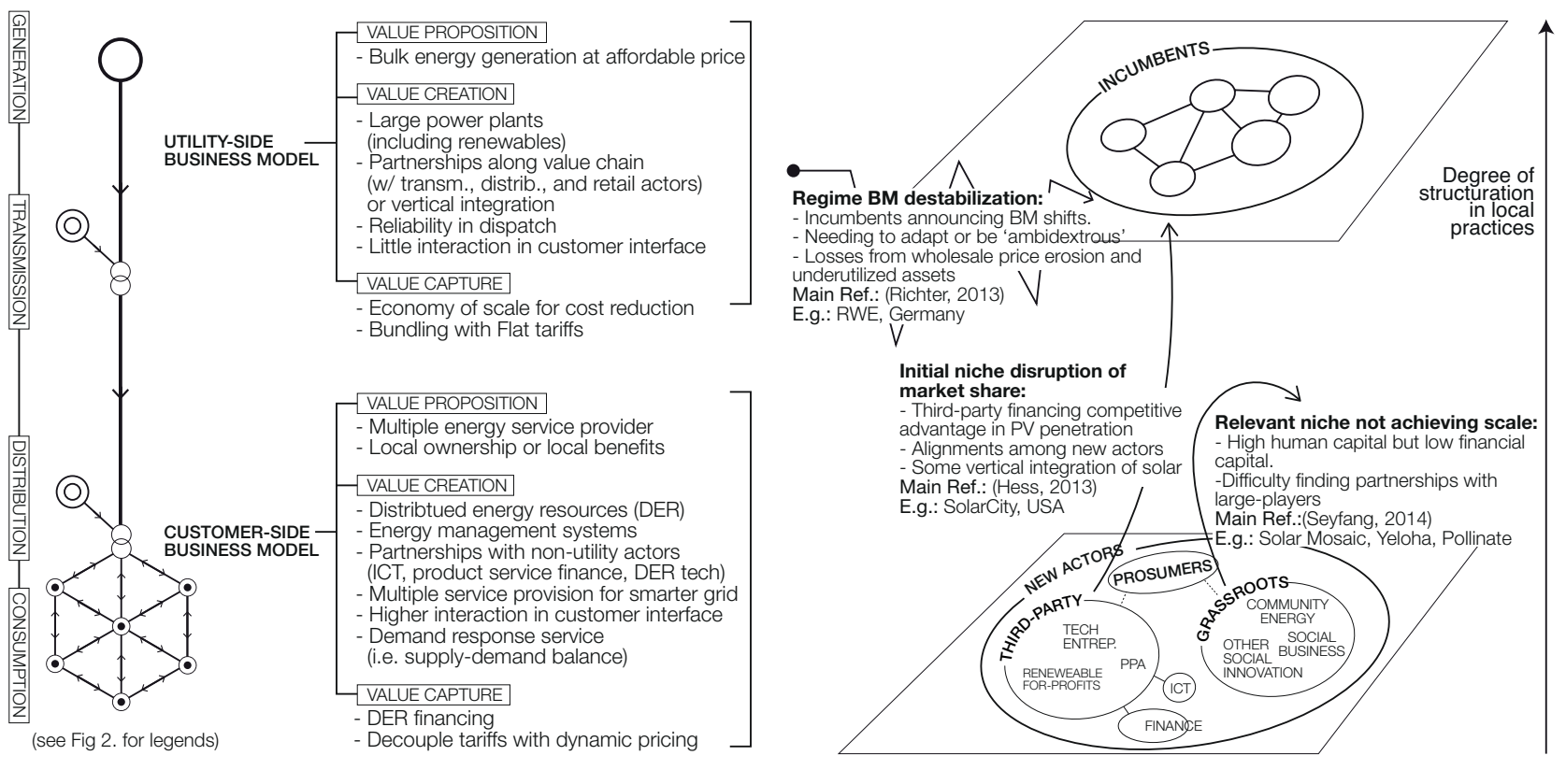

Figure 3. Summary of Business Model (BM) dynamics in the electricity sector. "Niche-regime" developments between incumbent utilities and new actors, emerging mostly due to opportunities in the distribution side of electricity. This combined figure shows, on the left, a description of the two main generic types of power system BM and, aligned to them on the right, an MLP arrangement of the three ongoing BM dynamics discussed in the paper, where customer-centric ones have the highest potential for innovation but still form a niche. Own heuristic illustration using references cited in section 3 and adapting MLP graphical language.

Nevertheless, grassroots initiatives are relevant since they are influential when introducing innovative BMs with increased customer participation.

Irrespective of the differences between both of these groups, their collective introduction of DERs is already making incumbent utilities face challenges in several fronts. Increasing ownership of renewable sources by these non-utility actors is leading to losses in market share (Klose et al., 2010; Schoettl and Lehmann-Ortega, 2011a). In Germany alone, utilities lost almost $90 \%$ of the market in renewable generation to third parties, representing around $24 \%$ of the total electricity generation market (AGEE-Stat, 2015; RAP, 2015). Denmark, one of the world's leaders in wind energy, has over $80 \%$ of wind farms that are either individually or cooperatively owned (Bolinger, 2001; Toke et al., 2008). These incoming renewable generation sources, due to merit order dispatch and a higher amount of excess capacity, produce profit erosions to utilities by reducing wholesale prices and volumes sold by higher marginal cost generators (Cludius et al., 2014; McConnell et al., 2013). Examples of such disrupted utilities include Alinta Energy from Australia, which recently announced an early shutdown of its South Australia power stations due to uneconomic performance resulting, primarily, from the state's high renewable penetration in recent years (AlintaEnergy, 2015; Robins, 2016). Incorporation of higher energy efficiency levels further erodes utility profits due to demand contraction, while reduction in peak demand events from demand response programs affects profitability of gas fired peak plants (eLAB, 2013). In turn, development and deployment of new DER technologies places pressure on utilities to find BMs that can integrate them and maximize their value. This is particularly challenging for established companies whose BM and current technology are still profitable, whilst new developments challenge existing practices (Christensen, 2013; Sosna et al., 2010). Based on these challenging factors, several large German utility firms announced that they will begin a process to reconfigure their conventional BM (Schlandt, 2015). This is also the case in Australia where large utilities have announced similar developments. For example AGL, the oldest Australian utility, underwent a corporate restructuring that includes investing in BM innovation for new renewable technology as part of their strategic roadmap (AGL, 2015a). Within a span of two years, it became one of the first large regime actors to provide the solar PPA BM for residential customers (Parkinson, 2015), began offering distributed battery storage solutions (AGL, 2015b), invested in Sunverge's battery aggregation BM (Kaye, 2016), and announced it will cease to pursue exploration and production of natural gas assets as a core business (AGL, 2016; Parkinson, 2016).

In essence, these studies suggest that BM innovation in distribution networks, which involve distributed generation among other services (with PV as its most iconic technology), are effectively driving an emerging niche in modern power systems irrespective of the underlying technology. This is largely due to the prowess of new commercial actors seizing the most market value from regulatory conditions and a change in value proposition, associated also with participation in grassroots and social-networked BMs. Although still not a disruptive niche, given a lack of commercial and financial power, these grassroots and social-networked BMs might be critical to shifts in customer participation. The incumbent utility-side BM, an element of the sociotechnical regime level, is already showing signs of destabilization with some actors undergoing initial reconfigurations. The right side of Figure 3 summarizes these main findings.

Based on these assumptions, we perform qualitative analyses of selected examples of BM and particular firms that best represent these three observations. We apply both BM and MLP framework to understand the main components 
that are factors of disruption and destabilization of these actors, or lack thereof. Namely, we examine the BM of third party financing of distributed solar in the U.S.A.; the BM with active customer participation in its value chain, with focus on P2P platforms and community projects; and finally the incumbent large utility BM.

\section{Power System Business Models and the Multilevel Perspective: Illustrative Examples}

This section presents and discusses three illustrative examples of transition-relevant BM using the MLP and the 9-point BM decomposition. The main BM-elements are summarized in Table 1.

\subsection{Financial innovation for niche scale: SolarCity, U.S.}

Power Purchase Agreements (PPA) are common tools used to ensure financial stability in many energy project developments, including large-scale renewables. But while conventional forms involve a project developer selling energy to an intermediate actor, in distributed solar the PPA is done directly with the residential or commercial enduser, as explained in the previous section. The main driver of this model could be attributed to its value proposition, which can be phrased as: "Pay for the electricity you consume, at a competitive rate, with no upfront cost." This value proposition is, in fact, the same as any conventional utility, where customers have a 'passive' role, and pay only what they consume. The value added difference is that this model involves a low carbon energy transaction, a fixed cost of electricity, often for 20 years with only inflationary adjustments, and the creation of a direct contact between the customer and the generation source. Historically, the main roadblock of the conventional BM for installing distributed PV systems has been attributed to the fact that customers face the full upfront cost, effectively becoming financiers of DERs (Frantzis et al., 2008). However, in a distributed solar PPA, the developer bears the upfront costs of the installation and retains ownership. This becomes a more capital intensive BM for the developer, but with virtually zero capital cost for customers, much like in centralized energy projects. Fig 4 shows a schematic diagram of the main dynamics and benefits involved in this model, which essentially turns the PV system from a product into a service.

The model was originally pioneered by SunEdison in 2003 and has been primarily implemented in the U.S.A., and has received greater stimulus with regulatory benefits. Aiming to increase renewable capacity in the U.S.A., the government introduced or extended several financial incentives and regulations by 2008 that acted as catalysts for the development of distributed solar (Haley and Schuler, 2011). One of the most important incentives is the Investment Tax Credits (ITC), which offers a 30\% tax credit for the total amount of capital invested in a PV project. Other federal incentives include a system for accelerated depreciation of the invested assets ${ }^{3}$, as well as specific cash grants for solar projects. Additionally, each state and local government may provide their own incentive in the form of grants, loans and rebates in order to achieve their own renewable portfolio goals ${ }^{4}$ (Hughes and Podolefsky, 2015). Finally, many states introduced laws for 'net metering,' which unlike a Feed-In Tariff, allows a customer with PV to exchange the surplus energy fed into the grid for a credit or offset of the energy purchased from the utility provider within the same billing period. Overall, these policy provisions help alleviate the upfront PV costs for home or commercial owners. But more importantly, they have been essential for solar developers to sustain the capital intensive PPA model, required to target homeowners for which even a subsidized upfront cost of PV is high or inconvenient. In fact, on top of the low-cost passive value proposition, the second driver of the solar PPA has been the financial innovation that solar developers used to maximize the benefits of these regulations (Mendelsohn et al., 2012).

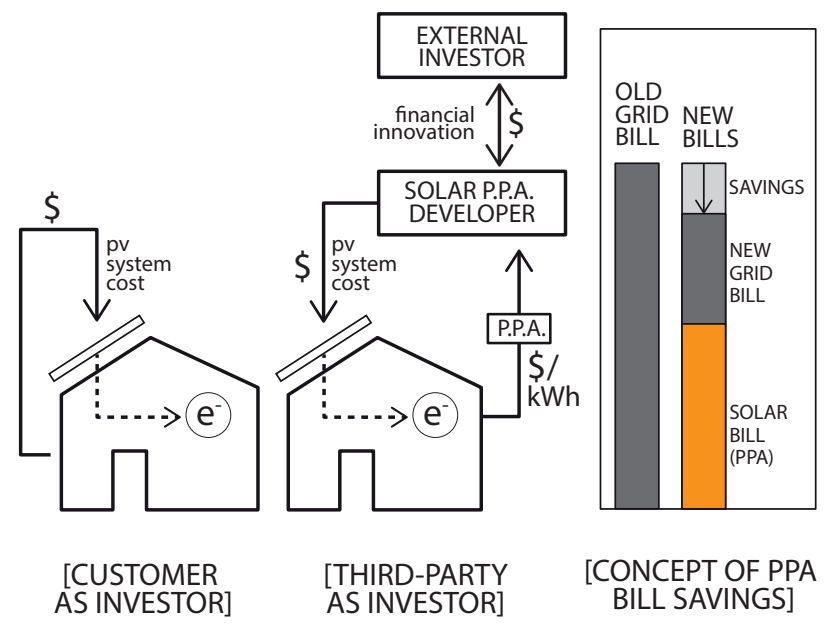

Figure 4. Distributed Solar PPA. Comparison of the PPA with the conventional scenario where customers must invest in the upfront cost of the PV system. Representation of the economic value proposition for customers with a PPA. Source:

Arguably a good example of a successful BM driving distributed solar projects with PPA is that of SolarCity Corporation, currently the largest U.S. solar company by 2014 revenue and market share (GTM, 2014). The three

\footnotetext{
${ }^{3}$ See, for example, the MACRS programs applicable for solar assets: www.irs.gov/

${ }^{4} \mathrm{See}$, for example, California Solar Initiative and other states at www.dsireusa.org/
} 
essential pillars for SolarCity's success and locus of BM innovation can be attributed to its: i) creative use of financial partnership structures to access large-scale capital; ii) aggressive sales and downstream partnerships to achieve scale in installation demand; and iii) a complete vertical integration of its value chain in order to minimize costs. Because of the nature of third-party PPA, financial innovation can be considered the most important factor since it's a prerequisite that drives the other two.

Founded in 2006 with $\$ 10 \mathrm{M}$ in venture capital, SolarCity acquired two local solar companies its first year of operation and began offering PPA and leasing as financial products, promoting its low capital cost value proposition (Newswire, 2006). By 2012, being already a frontrunner in national solar installations, it launched its Initial Public Offering (i.e. IPO) raising $\$ 92 \mathrm{M}$ from the stock market (SolarCity, 2012). However, the most important source of capital used to finance PV projects has been with tax equity investments. This form of financing, previously used in some wind projects, has now become a standard practice of the largest solar developers in the U.S (Mendelsohn et al., 2012). Since solar companies have very little 'tax liability,' in that they are not faced with large tax costs from profits, they cannot make full use of the $30 \%$ tax credit offered by the federal ITC. Therefore, solar companies began partnering with even larger, normally financial institutions, which are tax liable and can make full use of the solar tax credits (Lutton, 2013). The most common form of tax equity capital received by SolarCity involve what are called 'partnership flips.' SolarCity and a tax equity investor form a joint venture partnership to finance residential or commercial solar installations under a PPA. Investors provide most of the capital to the fund, pre-establish a desired return on their investment and, for at least the first 5 years retain most, if not all of the tax benefits by using them in their own balance sheets. Once the investor obtains its desired financial goal, SolarCity has the right to buy the investor's position in the fund (i.e. the "flip") and retain the cash benefits that the remaining PPA contracts provide. By 2015, SolarCity has manage to capture an accumulated $\$ 3 \mathrm{~B}$ in tax equity financing via partnerships with large corporations such as Google, BankOfAmerica, and GoldmanSachs (GTM, 2015; SolarCity, 2015b).

Tax equity structures produce returns-to-scale dynamics worth noticing. Due to the scale and complexity required, most tax equity investors will only join these partnerships if they can finance at least \$75-100 million worth of solar projects within one year (Lutton, 2013). For the residential sector, in order to make full use of the funds, this requires ensuring that several thousand financed PV systems will be installed consistently in a relative short period of time. Only solar companies that have enough sale and installation capacity can therefore access such large-scale financing. As such, SolarCity's BM focused on maximizing tax equity investments by having an aggressive sales strategy through multiple channels. For example, besides conventional forms of sales through online marketing and customer referrals, it partnered with homebuilders, large home developers like Pulte homes, and home improvement businesses such as HomeDepot, BestBuy and DirectTV which had already established access to homeowners (SolarCity, 2015a). This large networked sales strategy also increased the company's sales costs by $20 \%$ since its initial public offering (IPO), but was the only cost factor per installed solar Watt to have increased. In order to keep costs down, SolarCity, as well as other major developers, have recently become fully vertically integrated solar businesses.

Prior to the liberalization of electricity markets, most utilities had a vertically integrated BM controlling generation, transmission and distribution. These were kept as regulated monopolies since they ensured lower costs, maintaining the value proposition of reliable and affordable electricity. Similarly, SolarCity is now responsible for its entire solar value chain, having no transmission and distribution. In 2013, it acquired Silevo, a PV module manufacturer, in order to finalize its full integration covering module production, sales, finance, installation and full-lifespan maintenance, given it retains ownership of the solar assets. By being involved in all steps of the process, the company has been able to incorporate innovations in steps like PV mounting hardware (e.g. acquiring Zep Solar in 2013), alternative forms of leasing (Arfin, 2011), and software development in order to increase operation yields and reduce costs. Furthermore, this vertical integration has allowed SolarCity to further innovate in its BM by essentially dividing the company into two: a development company, which sells and installs systems, and a power company, which manages the generation assets selling electricity to customers.

At the time of this writing, SolarCity, has absorbed over $35 \%$ of the solar market share in the country, installed a cumulative PV portfolio of over $1.4 \mathrm{GW}$, and holds over $\$ 7.7 \mathrm{~B}$ contracted remaining payments, ranging among its quarter of a million clients (GTM, 2014; SolarCity, 2015c). Alongside its strong competitors like Vivint and FirstSolar, this customer-side solar sector has already been recognized as a disruptive niche (GTM/SEIA, 2014). Regime actors, which include U.S. largest utility companies, are already reacting to this threat. Although somehow harnessed from losses in electricity markets from state regulatory systems that decouple prices in order to protect customers and utilities (Kushler et al., 2006), the rapid loss in market share has made them lobby against the regulations largely responsible for catalyzing the rise of the solar niche, particularly the ITC and the net metering regulations (Farkas, 2012). In response, major solar developers have united through consolidated Industry associations to lobby in favor of regulations that allow PPA models to thrive.

While in the third-party solar PPA BM, the end-user can be considered a passive customer since it does not finance, own, nor is required to bear maintenance cost of the system, other BMs have developed in parallel where customers are not only active but an essential actor of the value chain.

\subsection{A socially active niche: Rise of the P2P and Community Energy}

Sociotechnical landscape shocks can introduce social discomfort that encourages some citizens to unite with a specific social agenda. Grassroots innovations can emerge under these circumstances, often helping introduce innovative BMs and political pressure towards sustainability (Ornetzeder and Rohracher, 2013). Modern wind energy in Denmark, for example, can be traced back to the OPEC oil embargo of 1974 (Danielsen and Halkier, 1995). With high 
oil prices, early discussions of developing nuclear energy for the country triggered the organization of local wind advocates that began experimenting with wind turbines to prove an alternative and safer form of energy. Climate change and the notion of 'peak oil' encouraged the beginning of several community energy projects in Europe (Bailey et al., 2010), whilst the global financial crisis influenced the acceleration of 'sharing economy' P2P Internet platforms (Botsman and Rogers, 2011). An underlying factor in these developments is active customer participation at a local level in response to a social need. From a BM perspective, this translates into customer co-participation in the value creation process, and a value proposition with a specific social agenda.

Socially active BMs are particularly relevant for the low carbon power system transition for at least two reasons. First, they form the backbone of community energy projects, which have proven to be successful in introducing decentralized clean energy supply in power networks of selected countries. Over $50 \%$ of Germany's renewable energy projects are community or locally-owned by citizens or cooperatives (ObservER, 2014). Depending on the nature of the project, these show commercial advantages over conventional private projects, such as in providing lower costs of capital, improving social acceptance of technology and accelerated municipal approval of energy developments (Bolinger, 2001; Maruyama et al., 2007). Second, customer-side BMs with user participation are essential in the value chain of a smarter and responsive power network hosting demand response programs. Just like the Web 2.0 introduced a two-way flow of information and user participation compared to its 1.0 counterpart (Carroll and Romano, 2010), a 2.0 power network with a resilient two-way flow of electrons will also require degrees of end-user interaction (Geelen et al., 2013; Goulden et al., 2014). BMs for demand response and smart grids are increasing source of research and entrepreneurial interest (Rodríguez-Molina et al., 2014). Understanding customer participation in BMs will be increasingly important as electricity networks continue to incorporate DERs (Verbong et al., 2013).

By applying the BM framework, specific traits can be found in customer-side BM with active user participation. Table 1 summarizes them in comparison to the other reviewed BM. A common trait among variations of their value proposition is increasing the level of local ownership (Hess, 2009). Therefore key resources in the BM are in fact the customer's assets, such as its product, financial power or even its knowhow, and the underlying social network that brings these together. The key activities become the actual P2P interactions, which organize around finding mutual opportunities. Whereas the conventional distribution channel to deliver these valued activities and interactions between customers was historically done through local assemblies and physical interactions, most of these have now evolved into P2P internet platforms that can host multiple interactions at virtually no extra cost (Bauwens, 2005a). Because of this, the most important BM partnerships are mostly internal, among customers and members, rather than with external parties. However, local governments are frequently sought, and even required, as strategic partners. The customer segment of these BMs is one of the most specific traits since it involves users that are willing to be active and participate. This is a stark contrast with the solar PPA, shown previously, where customers are virtually passive.

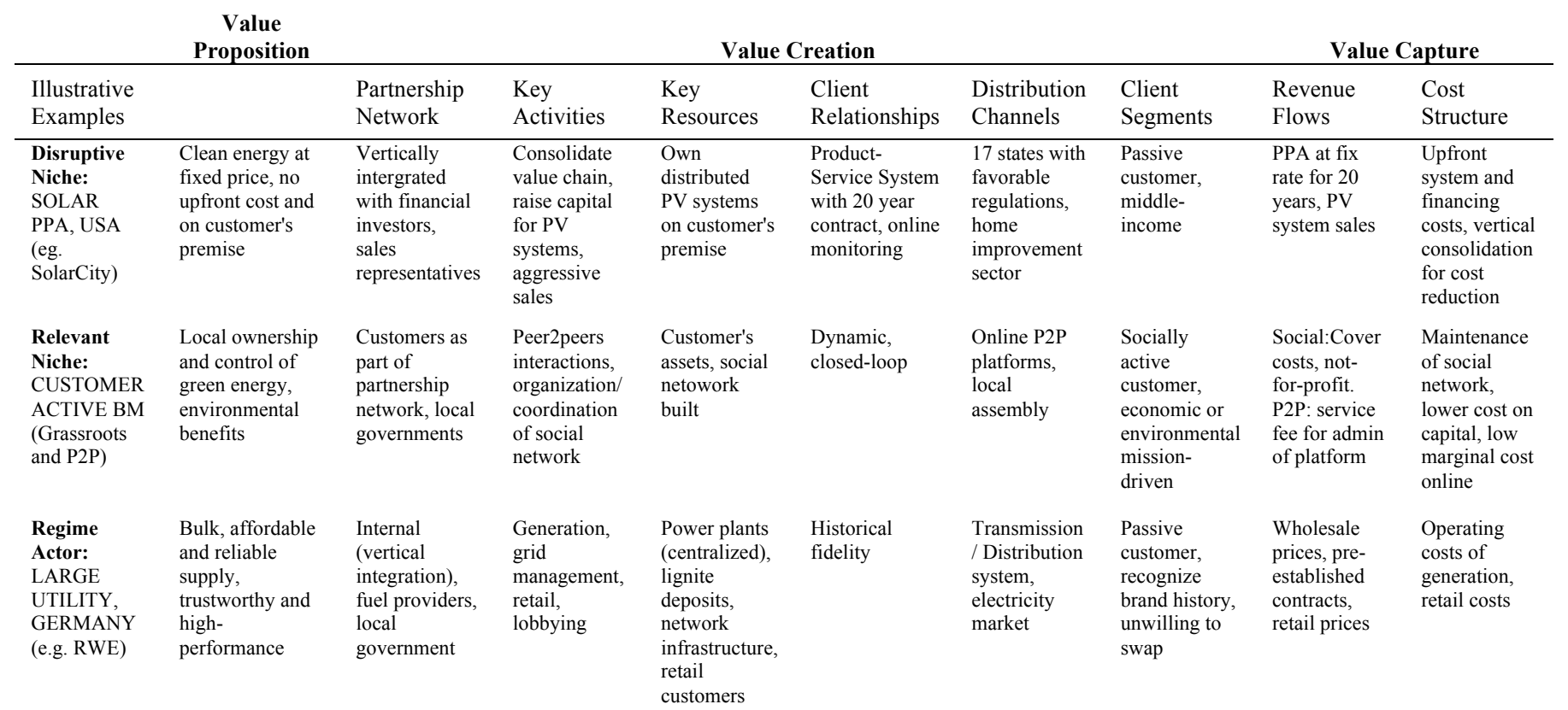

Table 1. Business model characterization of the illustrative examples presented. Note: the relevant niche of grassroots BMs are included here due to their future potential for disruption from the niche level as highlighted in section 4.2

When analyzing revenue and cost structures, as well as variation of the value proposition, two generic BMs with active customer participation can be distinguished. On one hand, those that are driven by an economic value proposition, such as optimization of resources for a product or service at a lower cost. These tend to provide improved commercial activity through joint value creations. On the other hand, there are those driven by addressing a specific social agenda. Nevertheless, both can be initially fostered by grassroots innovations. Modern car sharing BMs, for example, have evolved from initial grassroots developments in Switzerland, with first documented cases dating back to 1948 (Shaheen et al., 1998). The emerging and disruptive P2P economy is lead by profit-driven corporations, such as 
Airbnb and Uber, but they owe their innovative BM to initial local civil organizations seeking to maximize the value of their resources (e.g. reducing idle time) (Bauwens, 2005b). In fact, a main difference of the professional P2P corporation with the grassroots organization, is in its BM (Bauwens, 2009). In the former, the organization is a thirdparty that provides, organizes, administers and improves the P2P Internet platform in exchange for a service fee. Maximizing profit from an opportunity is the underlying purpose of a P2P corporation. Grassroots P2P networks, on the contrary, organize and administer themselves covering operating costs in order to maximize the value for their members. Furthermore, its purpose is measured based on how well it can address a specific social or environmental issue.

This niche is important since it's a source for radical BM innovation and can be an agent of influence in larger societal systems (Ornetzeder and Rohracher, 2013). However they are yet to be disruptive in the transition of the power networks. P2P-based firms have been disruptive in other sociotechnical systems, but developments in distributed energy have not achieved significant 'viral' effect ${ }^{5}$. This can be attributed to the heavily regulated nature and lock-in of the electricity system, resisting incorporation of more participative BM. Nevertheless some promising examples are worth noticing. The U.S. is seeing the birth of different solar based P2P BM. Mosaic, for example, uses a crowdfunding system to connect individual investors with homeowners that wish to have, but can't afford, a PV system (Chernova, 2013). Clean Energy Collective also uses crowdfunding but for regional members that wish to finance, own and operate a larger community-based solar systems and have their individual utility bills directly benefit from the production of this collective system (Coughlin et al., 2012; Sweet, 2015). Yeloha, on the other hand, uses a P2P platform to connect solar hosts, that can provide their rooftop for a PV system installation, with solar 'partners' that wish to finance and benefit from solar but have no physical rooftop access (Whitford, 2015). European examples tend to be less confined to solar PV systems, largely given a historic presence of community wind and biogas projects. Qurrent from the Netherlands, for example, enables local electricity networks between participants, allows them to crowdfund community windfarms and empowers them to manage their own energy. In turn, the company is a good example of a hybrid corporation since its a wholly owned subsidiary of a non-profit foundation, and are explicit about not having a shareholder maximization paradigm (Ceschin, 2013; DOEN, 2016).

Grassroots energy projects are extremely influential, but currently fail to achieve significant commercial scale in order to be classified as a disruptive niche (Seyfang et al., 2014). Although P2P-based energy is nascent, they are a potential source of future disruptive innovation in the socio-technical regime. As a result, further research is required in order to understand how to overcome the major roadblocks faced by these developments that, as pointed out, are central to a demand responsive low carbon power network.

\subsection{Initial utility BM destabilization: RWE, Germany}

Germany is the largest power generator in Europe (ObservER, 2014). Its Energiewende 6 is considered one of the most mature energy transition policy projects in the world. Renewables currently represent over $50 \%$ of the installed capacity (Fraunhofer, 2015). Although it is well-regarded for its ambitious environmental targets and green policy interventions, almost $90 \%$ of the electricity market is controlled by what are called the "Big 4," an oligopoly of vertically integrated multinational corporations: RWE, E.On, EnBW and Vattenfall (Sühlsen and Hisschemöller, 2014). This concentration is mostly due to the liberalization of its electricity market in 1998 with the Energy Industry Act (i.e. EnWG). It produced favorable conditions and opportunities for firms to focus on large-scale supply, expand activities beyond borders, and undergo mergers and acquisitions leading to these dominant actors forming the backbone of the energy regime (Kungl, 2014; Ratinen and Lund, 2014). When the Renewable Energy Sources Act (i.e. EEG), the main regulatory structure behind the Energiewende, was established in 2000, it hardly encouraged these actors to shift strategies or BM towards cleaner alternative. Instead, they maintained their focus on a fossil-nuclear supply portfolio, and lobbied against environmental regulations (Sühlsen and Hisschemöller, 2014). Since then, with the progression of the energy transition, several multi-level factors are making this regime lose resilience, destabilizing the firm's underlying BM (Strunz, 2014).

RWE is a useful example to study these incumbent utilities. Established in 1898, the firm is the leader and oldest actor of the German electricity market. Its vertical integration covers activities and resources in lignite production, power generation, trading, distribution network operation, and retail (RWE, 2014b). Its value proposition is based on the conventional utility-side BM of bulk and reliable supply, but also on its trustworthiness and high-performance from its long history. Because of its high level of vertical integration, the degree of partnerships with external parties is low. It does, however, include long-term agreements with power plants not owned by the group. Furthermore, as opposed to the other Big 4, it holds strong social ties and municipal shareholders favoring regional interests; factors that suggest a reduction in the likelihood of drastic diversification and organizational restructuring of the BM (Ratinen and Lund, 2014). Its customer segment builds on this traditional history and can be characterized as the conventional passive utility customer. Only as of 2007 did wind projects capture an increased interest and lead to the development of a specific unit, RWE Innogy: a utility-side developer of renewable projects with a strong focus on windfarms. Yet, as of 2014 RWE electricity production in Germany is composed primarily by lignite (52\%), followed by nuclear ( $21 \%)$, hard coal $(20 \%)$, gas $(4 \%)$ and only $1 \%$ renewables (RWE, 2014a). The revenue stream from this generation portfolio is largely dependent on wholesale electricity prices, fuel costs and emission allowances.

\footnotetext{
${ }^{5}$ Emerging opportunities, however, can be seen in new U.S. organizations such as Solar Mosaic or Yeloha.

${ }^{6}$ The German term for 'energy transition.'
} 
As in the rest of German energy regime, RWE experiences regime challenges in at least three fronts. Namely, the nuclear phase-out, the rapid increase in renewable market share by non-utility actors, and the erosion of wholesale electricity prices. The Fukushima nuclear disaster in 2011 also acted as a landscape shock. It accelerated the 2002 amendment of the Atomic Energy Act, ordering immediate decommissioning of the country's oldest eight nuclear reactors, a stepwise phase-out of the remaining plants by 2022, and a strengthening of policies towards renewables (Wittneben, 2012). The Big 4, being owners of all nuclear power plants in Germany, were the most vulnerable to this amendment. RWE had to shut down 2 of its 5 plants, losing a stable source of revenue and incurring decommissioning costs. These incumbents have resisted drastic changes in the regulatory environment with activities that include aggressive and professional lobbying. But once public perception was affected, as it was with Fukushima, these activities had to be revisited in order to protect corporate image and political bargaining power; suggested to have already been affected by this shock (Strunz, 2014; Sühlsen and Hisschemöller, 2014) .

In the case of market share loss by the hand of non-utility renewable developers and customers, no direct costs are incurred, but revenue losses from third-party competition produced pressures to develop a degree of ambidexterity in the market (Richter, 2013a). This is challenging for customer-side BMs, which involve different dynamics and capabilities than the bulk utility-side counterpart (Richter, 2013b). As demand response programs, DER aggregation and distributed storage take a critical role in balancing a market with high penetration of renewables, large utility firms like RWE will have to develop BMs that do not belong to their historical core business.

Even though these two described challenges are significant, the erosion of the German wholesale price is the most meaningful systemic signal of regime destabilization to highlight. Germany's market is particularly exposed to this effect only because its energy transition is mature; political proactivity lead to high penetration of renewables. Energy efficiency and a high penetration of variable renewables affect wholesale prices in competitive markets and thus disrupt revenue streams of incumbent utilities (Sensfuss et al., 2008). The sharp increase of PV penetration by 2010 and 2011 accelerated the "merit-order-effect" in Germany (Cludius et al., 2014). It is likely that wholesale price exposure of RWE was not as significant given backlogged price agreements for its generation up to 2012 (Kungl, 2014). By 2013, however, the exposure to prices was indeed more severe, becoming a main factor in the company's negative net income of $€ 2.8$ billion (RWE, 2013). Figure 5 shows a generic representation of how efficiency and centralized, decentralized and behind-the-meter renewables have reduced wholesale prices, affecting RWE's profit margins of conventional generators and peak-plants.

[WHOLESALE PRICE WITHOUT RENEWABLES]

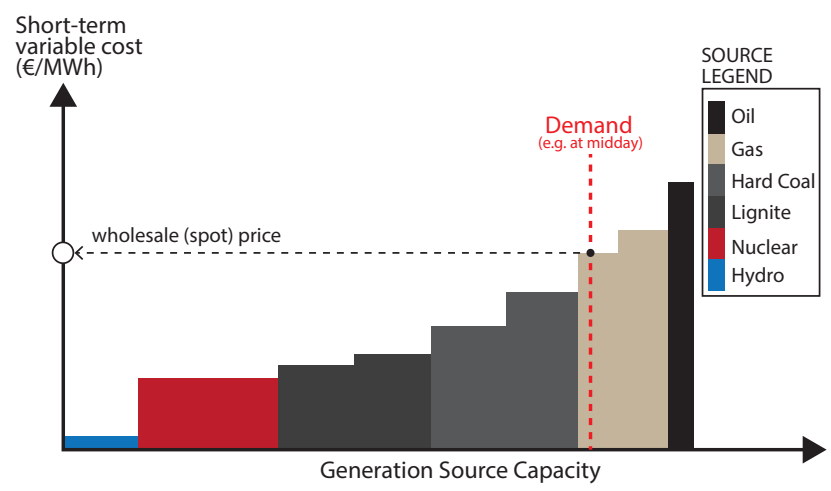

[WHOLESALE PRICE WITH MERIT-ORDER-EFFECT]

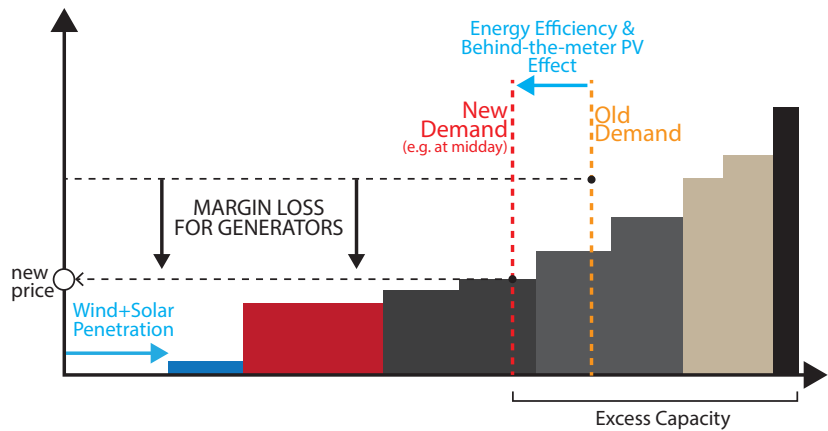

Figure 5. The Merit-Order Effect. Stylized graphical representation of the market effect responsible for the destabilization of the German utility BM through the erosion of wholesale prices.

These dynamics also have negative repercussions on renewable generators and customers (Hirth, 2013). In fact, since this market effect is expected with the rise of the renewable niche, this could have long-term implications on the electricity market design that would yield further destabilization of the incumbent $\mathrm{BM}^{7}$ (BDEW, 2013; Wassermann et al., 2015). In 2013, RWE publicly announced a change in its BM, understanding that the new market conditions are somehow irreversible (Beckman, 2013). E.On had a similar announcement (Jeevan Vasagar, 2015). Since then, RWE

${ }^{7}$ The eventual requirement of a revision or redesign of electricity markets is an on going debate. 
has made significant interventions on its cost structure and announced a strategy shift towards renewables and customer preferences (RWE, 2014a). Nevertheless, it is perhaps too soon to observe or predict the extent of the reconfiguration of its historical BM.

\section{Conclusions}

International negotiations to establish stricter climate targets and foster national energy transition projects may foster new investments and reductions in technology costs. However, our analysis suggests that BMs are a critical aspect in the acceleration of this process and should be analyzed accordingly. A positive feedback can be traced between disruptive BM innovation and the disrupted incumbent BM.

We have shown here that a change in value proposition can target a previously untapped mainstream customer segment, as shown with the example of third party financing and ownership of distributed solar PV. This tendency attracts partnerships with the financial sector, which is significant for enabling niche actors to scale up. Collectively, they help remove barriers to large-scale incorporation of DERs. Furthermore, a higher penetration of DERs and variable renewables can lead to a direct destabilization of the incumbent utility BM through the merit order effect in the electricity market. The more incumbents are forced to reconfigure their BM, the faster the power system undergoes a change in its paradigm, further accelerating this process. Eventually, systemic changes can occur, driven by revisions of the electricity market structure when faced with high presence of variable renewables, and with the change in the nature and distribution of key resources along the electricity supply chain.

Since the changes in the power system paradigm involve a more distributed, dynamic and participative nature, it presents further challenges to the incumbent BM, designed for a strictly centralized and passive system. These changes produce opportunities for BMs with increased customer participation, such as grassroots initiatives or more corporate oriented P2P-based BMs. We suggest these are 'relevant' niche actors given they have potential, but are yet to achieve scale and consolidate a market share.

Because of these dynamics, we expect BM to increasingly act as essential drivers of this transition. As such, the use of a conceptual framework combining BM with sociotechnical transition theory in the multi-level perspective has proven to be useful in highlighting specific dynamics in the low carbon transition. We suggest that analysis of BMs, therefore, should become an increasingly important role in future transition studies research. In turn, the paper shows how a MLP is useful for understanding the application of BM theory in the dynamics of the power system transition. In other words, the incorporation of BM theory into MLP theory, and vice versa, allows for a better understanding of how the low carbon sociotechnical transitions intersect with well-revised business dynamics of creative destruction, innovator's dilemma, and the Porter hypothesis. In fact, our study encourages drawing out and further studying the following proposition, which has meaningful practical implications for managers and regulators:

'Supported by stricter carbon regulations at an international geopolitical (landscape) level, an accelerated positive competition among regime and niche actors to develop BMs that can better anticipate customer needs in the low-carbon power system can be brought about by: national and subnational policymakers (regime actors) ensuring a suitable regulatory framework for BM innovation in their respective electricity networks, particularly those that allow for innovative financial schemes, a two-way integration of DERs, and those that foster and reward customer participation and socially driven firms (niche disruptors, and relevant niche actors). Ultimately, this process could bring about a change in wealth and a shift in the power system infrastructural landscape and paradigm, from overly centralized to a mixed distributed energy system.'

This work, therefore, presents interesting opportunities for a research agenda in both business and sociotechnical transitions studies. If, in fact, grassroots and P2P initiatives could have a central and disruptive role in the power system shift towards a smarter and responsive grid, what exactly would this role be in terms of tangible BMs? How can these BMs achieve scale for a true disruptive influence? In parallel to the notion of active customers, if indeed another big segment of the mainstream market seeks low capital cost models such as the PPA, what other BM and regulatory factors could be considered to incentivize the financial system to have a central role in DER or low carbon energy financing? Finally, to what extend can the large utility BM actually reconfigure and adapt without being severely affected by a large number of costly underutilized centralized assets? How will possible changes in modernized electricity market design further affect this utility BM adaptation? These are all questions that point to the importance of understanding business models as a driver of the low carbon power system transition. 
AGEE-Stat, 2015. Development of renewable energy sources in Germany 2014, Charts and figures based on statistical data from the Working Group on Renewable Energy-Statistics (AGEE-Stat), as at February 2015. BMWI.

Aghaei, J., Alizadeh, M.-I., 2013. Demand response in smart electricity grids equipped with renewable energy sources: A review. Renewable and Sustainable Energy Reviews 18, 64-72.

AGL, 2015a. AGL Annual Report 2015, in: http://www.agl.com.au (Ed.), Annual Report, https://www.agl.com.au/ /media/AGL/About AGL/Documents/Investor Centre/150826_AnnualReport_1466512.pdf. AGL, 2015b. AGL is first major retailer to launch battery storage, in: Lamond, K. (Ed.). http://www.agl.com.au, https://www.agl.com.au/about-agl/media-centre/article-list/2015/may/agl-is-first-major-retailer-to-launch-batterystorage.

AGL, 2016. Review of gas assets and exit of gas exploration and production, in: Rizgalla, N. (Ed.). agl.com.au, https://www.agl.com.au/about-agl/media-centre/article-list/2016/february/review-of-gas-assets-and-exit-of-gasexploration-and-production.

AlintaEnergy, 2015. Flinders Operation Announcement, in: Alinta (Ed.), https://alintaenergy.com.au/about-us/news/flindersoperations-announcement.

Amit, R., Zott, C., 2001. Value creation in e - business. Strategic management journal 22, 493-520.

Andersson, M., 2013. Peer-to-peer service sharing platforms: Driving share and share alike on a mass-scale International Conference on Information Systems (ICIS 2013): Reshaping Society Through Information Systems Design. Arfin, D., 2011. Methods for financing renewable energy systems. Google Patents.

Baden-Fuller, C., Morgan, M.S., 2010. Business Models as Models. Long Range Planning 43, 156-171.

Bailey, I., Hopkins, R., Wilson, G., 2010. Some things old, some things new: the spatial representations and politics of change of the peak oil relocalisation movement. Geoforum 41, 595-605.

Bauwens, M., 2005a. P2P and Human Evolution: Peer to peer as the premise of a new mode of civilization. Ensaio, rascunho 1. Bauwens, M., 2005b. The political economy of peer production. CTheory 1.

Bauwens, M., 2009. Class and capital in peer production. Capital \& Class 33, 121-141.

BDEW, 2013. The pathway to new market structures for the success of the energy transition (Energiewende). BDEW German Association of Energy and Water Industries.

Beckman, K., 2013. Exclusive: RWE sheds old business model, embraces transition, in: EnergyPost (Ed.). EnergyPost, http://www.energypost.eu/exclusive-rwe-sheds-old-business-model-embraces-energy-transition/. Belk, R., 2014. You are what you can access: Sharing and collaborative consumption online. Journal of Business Research 67, 15951600 .

Bidmon, C.M., Knab, S., 2014. The Three Roles of Business Models for Socio-technical Transitions, XXV ISPIM Conference, Dublin, Ireland, June 8-11, 2014; Winner of the Aalto University That's Interesting! Award.

Biello, D., 2014. Fight over Rooftop Solar Forecasts a Bright Future for Cleaner Energy, Scientific American, http://www.scientificamerican.com/article/fight-over-rooftop-solar-forecasts-a-bright-future-for-cleaner-energy/. Bocken, N.M.P., Short, S.W., Rana, P., Evans, S., 2014. A literature and practice review to develop sustainable business model archetypes. Journal of Cleaner Production 65, 42-56.

Bolinger, M., 2001. Community wind power ownership schemes in Europe and their relevance to the United States. Lawrence Berkeley National Laboratory.

Boons, F., Lüdeke-Freund, F., 2013. Business models for sustainable innovation: state-of-the-art and steps towards a research agenda. Journal of Cleaner Production 45, 9-19.

Boons, F., Montalvo, C., Quist, J., Wagner, M., 2013. Sustainable innovation, business models and economic performance: an overview. Journal of Cleaner Production 45, 1-8.

Botsman, R., Rogers, R., 2011. What's mine is yours: how collaborative consumption is changing the way we live. Collins London. Bumpus, A., Tansey, J., Henríquez, B.L.P., Okereke, C., 2014. Carbon governance, Climate change and business transformation. Routledge.

Carroll, E., Romano, J., 2010. Your Digital Afterlife: When Facebook, Flickr and Twitter are Your Estate, What's Your Legacy? New Riders.

Ceschin, F., 2013. Critical factors for implementing and diffusing sustainable product-Service systems: insights from innovation studies and companies' experiences. Journal of Cleaner Production 45, 74-88.

Charitou, C.D., Markides, C.C., 2012. Responses to disruptive strategic innovation. MIT Sloan Management Review, Vol.À̀ , N ${ }^{\circ} \bar{A}$ Chernova, Y., 2013. Want to Invest a Few Hundred Bucks in a Solar Project? Mosaic Opens Crowdfunding Platform, The Wall Street Journal. WSJ, http://blogs.wsj.com/venturecapital/2013/01/08/want-to-invest-a-few-hundred-bucks-in-a-solarproject-mosaic-opens-crowdfunding-platform/.

Chesbrough, H., 2007. Business model innovation: It's not just about technology anymore. Strategy and Leadership 35, 12-17. Chesbrough, H., 2010. Business model innovation: opportunities and barriers. Long range planning 43, 354-363.

Chesbrough, H., Rosenbloom, R.S., 2002. The role of the business model in capturing value from innovation: evidence from Xerox Corporation's technology spin - off companies. Industrial and corporate change 11, 529-555.

Chesbrough, H.W., Appleyard, M.M., 2007. Open innovation and strategy.

Christensen, C., 1997. The innovator's dilemma: when new technologies cause great firms to fail. Harvard Business Review Press. Christensen, C., 2013. The innovator's dilemma: when new technologies cause great firms to fail. Harvard Business Review Press. Christensen, C.M., Raynor, M.E., 2003. The innovator's solution. Harvard Business Press.

Cludius, J., Hermann, H., Matthes, F.C., Graichen, V., 2014. The merit order effect of wind and photovoltaic electricity generation in Germany 2008-2016 estimation and distributional implications. Energy Economics 44, 302-313.

Coughlin, J., Grove, J., Irvine, L., Jacobs, J.F., Phillips, S.J., Sawyer, A., Wiedman, J., 2012. A Guide to Community Shared Solar: Utility, Private, and Nonprofit Project Development. US Department of Energy, SunShot Initiative. DOE/GO-102012-3569.

Dangerman, A.T.C.J., Schellnhuber, H.J., 2013. Energy systems transformation. Proceedings of the National Academy of Sciences 110, E549-E558. 
Danielsen, O., Halkier, B., 1995. Renewable Energy in the Danish Energy System: From Small Experiments to Full Scale Energy Plants : Danish Contribution to the Projekt Pathways from Small Scale Experiments to Sustainable Regional Development, "Express Path", CEC Contract No. EV5V-CT92-0086. Roskilde University.

Dees, G.A., Beth, 2003. For-Profit Social Ventures. International Journal of Entrepreneurship Education 2.

DOEN, 2016. Qurrent, in: Foundation, D. (Ed.), DOEN Projects, http://www.doen.nl/web/projecten-die-weDOEN/Groen/Qurrent-1.htm.

eLAB, 2013. New Business Models for the Distribution Edge. Rocky Mountain Institute.

Elzen, B., Geels, F., Hofman, P., 2002. Sociotechnical Scenarios (STSc): Development and evaluation of a new methodology to explore transitions towards a sustainable energy supply.

Esposito, R.T., 2012. Social Enterprise Revolution in Corporate law: A Primer on Emerging Corporate Entities in Europe and the United States and the Case for the Benefit Corporation, The. Wm. \& Mary Bus. L. Rev. 4, 639.

Evans, J.P., 2011. Environmental governance. Routledge.

Farkas, S., 2012. THIRD-PARTY PPAs: UNLEASHING AMERICA'S SOLAR POTENTIAL. Journal of Land Use \& Environmental Law 28, 91-118.

Frankel, D., Ostrowski, K., Pinner, D., 2014. The disruptive potential of solar power. McKinsey Quarterly, April.

Frantzis, L., Graham, S., Katofsky, R., Sawyer, H., 2008. Photovoltaics business models. National Renewable Energy Laboratory Burlington.

Fraunhofer, 2015. Net installed electricity generation capacity in Germany, Energy Charts. Fraunhofer ISE.

Frei, C.W., 2008. What if...? Utility vision 2020. Energy Policy 36, 3640-3645.

Geelen, D., Reinders, A., Keyson, D., 2013. Empowering the end-user in smart grids: Recommendations for the design of products and services. Energy Policy 61, 151-161.

Geels, F.W., 2002. Technological transitions as evolutionary reconfiguration processes: a multi-level perspective and a case-study. Research Policy 31, 1257-1274.

Geels, F.W., 2004. From sectoral systems of innovation to socio-technical systems. Research Policy 33, 897-920.

Geels, F.W., 2005. Technological Transitions and System Innovations: A Co-evolutionary and Socio-technical Analysis. Edward Elgar Publishing, Incorporated.

Geels, F.W., 2011. The multi-level perspective on sustainability transitions: Responses to seven criticisms. Environmental Innovation and Societal Transitions 1, 24-40.

Geels, F.W., 2012. A socio-technical analysis of low-carbon transitions: introducing the multi-level perspective into transport studies. Journal of Transport Geography 24, 471-482.

Geels, F.W., 2014. Regime Resistance against Low-Carbon Transitions: Introducing Politics and Power into the Multi-Level Perspective. Theory, Culture \& Society 31, 21-40.

Gelbmann, U., Hammerl, B., 2014. Integrative re-use systems as innovative business models for devising sustainable productservice-systems. Journal of Cleaner Production.

George, G., Bock, A.J., 2011. The business model in practice and its implications for entrepreneurship research. Entrepreneurship theory and practice $35,83-111$.

Goulden, M., Bedwell, B., Rennick-Egglestone, S., Rodden, T., Spence, A., 2014. Smart grids, smart users? The role of the user in demand side management. Energy Research \& Social Science 2, 21-29.

Grin, J., Rotmans, J., Schot, J., 2010. Transitions to Sustainable Development: New Directions in the Study of Long Term Transformative Change. Taylor \& Francis.

GTM, R., 2014. U.S. PV Leaderboard. GTM Research.

GTM, R., 2015. Which Residential Solar Firms Have Raised the Most Tax Equity?, in: Pyper, J. (Ed.). Greentechmedia, http://www.greentechmedia.com/articles/read/where-did-tax-equity-investors-spend-money-in-2014.

GTM/SEIA, 2014. Solar Market Insight. GTM Research, http://www.greentechmedia.com/research.

Haley, U.C.V., Schuler, D.A., 2011. Government Policy and Firm Strategy in the Solar Photovoltaic Industry. California

Management Review 54, 17-38.

Hargreaves, T., Longhurst, N., Seyfang, G., 2013. Up, down, round and round: connecting regimes and practices in innovation for sustainability. Environment and Planning A 45, 402-420.

He, X., Delarue, E., D'Haeseleer, W., Glachant, J.-M., 2011. A novel business model for aggregating the values of electricity storage. Energy Policy 39, 1575-1585.

Hess, D., 2009. Localist movements in a global economy. Cambridge, MA: MIT Press.

Hess, D.J., 2013. Industrial fields and countervailing power: The transformation of distributed solar energy in the United States.

Global Environmental Change-Human and Policy Dimensions 23, 847-855.

Hirth, L., 2013. The market value of variable renewables: The effect of solar wind power variability on their relative price. Energy

Economics 38, 218-236.

Hughes, J.E., Podolefsky, M., 2015. Getting Green with Solar Subsidies: Evidence from the California Solar Initiative. Journal of the Association of Environmental and Resource Economists 2, 235-275.

Huijben, J.C.C.M., Verbong, G.P.J., 2013. Breakthrough without subsidies? PV business model experiments in the Netherlands. Energy Policy 56, 362-370.

IEA, 2014. Key World Energy Statistics, IEA Reports. International Energy Agency.

Ipakchi, A., Albuyeh, F., 2009. Grid of the future. Power and Energy Magazine, IEEE 7, 52-62.

IPCC, 2013. Summary for Policymakers, in: Stocker, T.F., D. Qin, G.-K. Plattner, M. Tignor, S.K. Allen, J. Boschung, A. Nauels, Y. Xia, V. Bex and P.M. Midgley (Ed.), Climate Change 2013: The Physical Science Basis. Contribution of Working Group I to the Fifth Assessment Report of the Intergovernmental Panel on Climate Change. Cambridge University Press, Cambridge, United Kingdom and New York, NY, USA, pp. 1-29.

Jeevan Vasagar, B.a.P.C., 2015. Germany's green goals have profound consequences for Eon and RWE, Financial Times, ft.com. John, J., 2014. Will Utilities Control Behind-the-Meter Solar Batteries?, in: Lacey, S. (Ed.), GreenTechMedia. GTM,

http://www.greentechmedia.com/articles/read/will-utilities-control-behind-the-meter-solar-batteries.

Kaye, B., 2016. Australia's AGL Energy enters competitive batteries market with stake buy, Reuters. http://www.reuters.com, http://www.reuters.com/article/agl-energy-australia-gas-idUSL3N15O3QK. 
Kemp, R., Schot, J., Hoogma, R., 1998. Regime shifts to sustainability through processes of niche formation: the approach of strategic niche management. Technology analysis \& strategic management 10, 175-198.

Keskin, D., Diehl, J.C., Molenaar, N., 2013. Innovation process of new ventures driven by sustainability. Journal of Cleaner Production 45, 50-60.

Klose, F., Kofluk, M., Lehrke, S., Rubner, H., 2010. Toward a distributed-power world. Renewables and smart grids will reshape the energy sector. The Boston Consulting Group Report.

Kriegler, E., Weyant, J.P., Blanford, G.J., Krey, V., Clarke, L., Edmonds, J., Fawcett, A., Luderer, G., Riahi, K., Richels, R., 2014.

The role of technology for achieving climate policy objectives: overview of the EMF 27 study on global technology and climate policy strategies. Climatic Change 123, 353-367.

Kungl, G., 2014. The incumbent German power companies in a changing environment: A comparison of E. ON, RWE, EnBW and Vattenfall from 1998 to 2013. Stuttgarter Beiträge zur Organisations-und Innovationsforschung, SOI Discussion Paper.

Kushler, M., York, D., Witte, P., 2006. Aligning utility interests with energy efficiency objectives: A review of recent efforts at decoupling and performance incentives. American Council for an Energy Efficient Economy.

Loorbach, D., Wijsman, K., 2013. Business transition management: exploring a new role for business in sustainability transitions. Journal of Cleaner Production 45, 20-28.

Lovins, A.B., Lovins, L.H., Hawken, P., 1999. A road map for natural capitalism. Harvard business review 77, 145-158, 211.

Lutton, J., 2013. Tax Equity 101: Structures. Woodlawn Associates, http://www.woodlawnassociates.com/.

Markides, C., 2006. Disruptive innovation: In need of better theory*. Journal of product innovation management 23, $19-25$.

Markides, C., Charitou, C.D., 2004. Competing with dual business models: A contingency approach. Academy of Management Executive 18, 22-36.

Maruyama, Y., Nishikido, M., Iida, T., 2007. The rise of community wind power in Japan: Enhanced acceptance through social innovation. Energy Policy 35, 2761-2769.

McConnell, D., Hearps, P., Eales, D., Sandiford, M., Dunn, R., Wright, M., Bateman, L., 2013. Retrospective modeling of the meritorder effect on wholesale electricity prices from distributed photovoltaic generation in the Australian National Electricity Market. Energy Policy 58, 17-27.

Mendelsohn, M., Kreycik, C., Bird, L., Schwabe, P., Cory, K., 2012. The impact of financial structure on the cost of solar energy. Contract 303, 275-3000.

Mickels, A., 2009. Beyond corporate social responsibility: Reconciling the ideals of a for-benefit corporation with director fiduciary duties in the US and Europe. Hastings Int'l \& Comp. L. Rev. 32, 271.

Miles, R.E., Miles, G., Snow, C.C., 2006. Collaborative Entrepreneurship:: A Business Model for Continuous Innovation.

Organizational Dynamics 35, 1-11.

Morris, M., Schindehutte, M., Allen, J., 2005. The entrepreneur's business model: toward a unified perspective. Journal of business research 58, 726-735.

Murray, J., 2012. Choose Your Own Master: Social Enterprise, Certifications and Benefit Corporation Statutes. Choose Your Own Master: Social Enterprise, Certifications and Benefit Corporation Statutes (June 15, 2012) 2.

Newswire, P., 2006. SolarCity Acquires Palo Alto Solar and Declination Solar. PR Newswire http://www.prnewswire.com/newsreleases/solarcity-acquires-palo-alto-solar-and-declination-solar-57202837.html.

O'Connell, N., Pinson, P., Madsen, H., O'Malley, M., 2014. Benefits and challenges of electrical demand response: A critical review. Renewable and Sustainable Energy Reviews 39, 686-699.

ObservER, 2014. The State of Renewable Energies in Europe, in: Seigneur, V.J.1. (Ed.), EurOberv'ER.

Ornetzeder, M., Rohracher, H., 2013. Of solar collectors, wind power, and car sharing: comparing and understanding successful cases of grassroots innovations. Global Environmental Change 23, 856-867.

Osterwalder, A., 2004. The business model ontology - A proposition in a design science approach. The Business Model Ontology - a proposition in a design science approach.

Osterwalder, A., 2005. What is a Business Model?, in: Osterwalder, A. (Ed.), Business Model Alchemist.

Osterwalder, A., Pigneur, Y., 2010. Business model generation: a handbook for visionaries, game changers, and challengers. John Wiley \& Sons.

Osterwalder, A., Pigneur, Y., Tucci, C.L., 2005. Clarifying business models: Origins, present, and future of the concept. Communications of the association for Information Systems 16, 1.

Parkinson, G., 2015. AGL Energy becomes first big retailer to roll out solar PPA plan, in: Parkinson, G. (Ed.), RenewEconomy. reneweconomy.com.au, http://reneweconomy.com.au/2015/agl-energy-becomes-first-big-retailer-to-roll-out-solar-ppaplan-96323.

Parkinson, G., 2016. AGL quits coal seam gas, to focus on "energy evolution”, in: Parkinson, G. (Ed.), RenewEconomy. reneweconomy.com.au, http://reneweconomy.com.au/2016/agl-quits-gas-production-to-focus-on-energy-transformation55770.

Phills, J.A., Deiglmeier, K., Miller, D.T., 2008. Rediscovering social innovation. Stanford Social Innovation Review 6, 34-43. RAP, 2015. Report on the German power system. Study commissioned by Agora Energiewende.

Ratinen, M., Lund, P.D., 2014. Growth strategies of incumbent utilities as contextually embedded: Examples from Denmark, Germany, Finland and Spain. Technology in Society 38, 81-92.

Ray, S., Munksgaard, J., Morthorst, P.E., Sinner A-F., 2010. Wind Energy and Electricity Prices: Exploring the'merit Order Effect'. EWEA.

Ribeiro-Soriano, D., Urbano, D., 2009. Overview of collaborative entrepreneurship: an integrated approach between business decisions and negotiations. Group Decision and Negotiation 18, 419-430.

Richter, M., 2012. Utilities' business models for renewable energy: A review. Renewable and Sustainable Energy Reviews 16, 24832493.

Richter, M., 2013a. Business model innovation for sustainable energy: German utilities and renewable energy. Energy Policy 62, 1226-1237.

Richter, M., 2013b. German utilities and distributed PV: How to overcome barriers to business model innovation. Renewable Energy 55, 456-466. 
Robins, B., 2016. Will the future arrive in time to head off the emerging energy crisis? Sydney Morning Herald.

http://www.smh.com.au/business/energy/will-the-future-arrive-in-time-to-head-off-the-emerging-crisis-20160203-gmlb0z.html Accessed: 17 Feb 2016

Rodríguez-Molina, J., Martínez-Núñez, M., Martínez, J.-F., Pérez-Aguiar, W., 2014. Business Models in the Smart Grid: Challenges, Opportunities and Proposals for Prosumer Profitability. Energies 7, 6142-6171.

Rogelj, J., Luderer, G., Pietzcker, R.C., Kriegler, E., Schaeffer, M., Krey, V., Riahi, K., 2015. Energy system transformations for limiting end-of-century warming to below 1.5 [deg]C. Nature Clim. Change 5, 519-527.

RWE, 2013. Annual Report, in: http://www.rwe.com (Ed.), https://www.rwe.com/web/cms/en/1838136/rwe/investorrelations/reports/2013/.

RWE, 2014a. Annual Report, in: http://www.rwe.com (Ed.), http:/www.rwe.com/web/cms/en/2331574/rwe/investorrelations/reports/2014/.

RWE, 2014b. Facts \& Figures - Presentation, in: rwe.com (Ed.), http://www.rwe.com/web/cms/en/2495606/rwe/investorrelations/presentations/.

Salkin, P., 2012. THE KEY TO UNLOCKING THE POWER OF SMALL SCALE RENEWABLE ENERGY: LOCAL LAND USE REGULATION. Journal of Land Use \& Environmental Law 27, 339-367.

Schlandt, J., 2015. Fighting for survival: Germany's big utilities look for a future in the new energy world, in: Wire, C.E. (Ed.). Clean Energy Wire, cleanenergywire.org.

Schleicher-Tappeser, R., 2012. How renewables will change electricity markets in the next five years. Energy policy 48, 64-75. Schneider, 2015. Virtual Power Plant: Solution to Utility Concerns on Integrating Distributed Residential Solar and Storage, in: SAS, S.E.I. (Ed.), Schneideer Electric Case Study, http://solar.schneider-electric.com/virtual-power-plant-solution-to-utilityconcerns-on-integrating-distributed-residential-solar-and-storage/.

Schoettl, J., Lehmann-Ortega, L., 2011a. Photovoltaic business models: threat or opportunity for utilities. Handbook of research on energy entrepreneurship. Edward Elgar, Cheltenham, 145-171.

Schoettl, J.M., Lehmann-Ortega, L., 2011b. Photovoltaic business models: Threat or opportunity for utilities? Handbook of Research on Energy Entrepreneurship, 145-171.

Sensfuss, F., Ragwitz, M., Genoese, M., 2008. The merit-order effect: A detailed analysis of the price effect of renewable electricity generation on spot market prices in Germany. Energy policy 36, 3086-3094.

Seyfang, G., Haxeltine, A., 2012. Growing grassroots innovations: exploring the role of community-based initiatives in governing sustainable energy transitions. Environment and Planning C-Government and Policy 30, 381-400.

Seyfang, G., Hielscher, S., Hargreaves, T., Martiskainen, M., Smith, A., 2014. A grassroots sustainable energy niche? Reflections on community energy in the UK. Environmental Innovation and Societal Transitions.

Shackley, S., Green, K., 2007. A conceptual framework for exploring transitions to decarbonised energy systems in the United Kingdom. Energy 32, 221-236.

Shaheen, S., Sperling, D., Wagner, C., 1998. Carsharing in Europe and North American: past, present, and future.

Siano, P., 2014. Demand response and smart grids-A survey. Renewable and Sustainable Energy Reviews 30, 461-478.

Sioshansi, F.P., 2006. Electricity Market Reform: What Have We Learned? What Have We Gained? The Electricity Journal 19, 7083.

SolarCity, 2012. SolarCity Announces Pricing of its Initial Public Offering. SolarCity,

http://www.solarcity.com/newsroom/press/solarcity-announces-pricing-its-initial-public-offering.

SolarCity, 2015a. Investor Presentation. SolarCity, http://investors.solarcity.com/events.cfm.

SolarCity, 2015b. SolarCity and Bank of America Merrill Lynch Create New Program to Give Diverse Range of Investors Access to

Tax Equity Investments. SolarCity Newsroom.

SolarCity, 2015c. SolarCity Second Quarter 2015 Shareholder Letter. SolarCity.

Sosna, M., Trevinyo-Rodríguez, R.N., Velamuri, S.R., 2010. Business model innovation through trial-and-error learning: The Naturhouse case. Long range planning 43, 383-407.

Strbac, G., 2008. Demand side management: Benefits and challenges. Energy policy 36, 4419-4426.

Strunz, S., 2014. The German energy transition as a regime shift. Ecological Economics 100, 150-158.

Sühlsen, K., Hisschemöller, M., 2014. Lobbying the 'Energiewende'. Assessing the effectiveness of strategies to promote the renewable energy business in Germany. Energy Policy 69, 316-325.

Sweet, C., 2015. Solar-Power Sharing Programs May Be Poised to Take Off, in: Gigot, P. (Ed.), The Wall Street Journal. WSJ, http://www.wsj.com/article email/solar-power-sharing-programs-may-be-poised-to-take-off-1442197726-

MyQjAxMTA1ODE1NDAxODQ4Wj.

Teece, D.J., 2010. Business models, business strategy and innovation. Long range planning 43, 172-194.

Toke, D., Breukers, S., Wolsink, M., 2008. Wind power deployment outcomes: How can we account for the differences? Renewable and sustainable energy reviews 12, 1129-1147.

Tongur, S., Engwall, M., 2014. The business model dilemma of technology shifts. Technovation 34, 525-535.

UNFCCC, 2015. Adoption of the Paris Agreement, available at:

https://unfccc.int/documentation/documents/advanced search/items/6911.php?priref=600008831.

Unruh, G.C., 2000. Understanding carbon lock-in. Energy Policy 28, 817-830.

Urry, J., 2014. The Problem of Energy. Theory, Culture \& Society 31, 3-20.

Verbong, G., Geels, F., 2007. The ongoing energy transition: Lessons from a socio-technical, multi-level analysis of the Dutch electricity system (1960-2004). Energy Policy 35, 1025-1037.

Verbong, G.P., Beemsterboer, S., Sengers, F., 2013. Smart grids or smart users? Involving users in developing a low carbon electricity economy. Energy Policy 52, 117-125.

Verbong, G.P.J., Geels, F.W., 2010. Exploring sustainability transitions in the electricity sector with socio-technical pathways.

Technological Forecasting and Social Change 77, 1214-1221.

Wassermann, S., Reeg, M., Nienhaus, K., 2015. Current challenges of Germany's energy transition project and competing strategies of challengers and incumbents: The case of direct marketing of electricity from renewable energy sources. Energy Policy 76, 66-75. Weerawardena, J., Mort, G.S., 2006. Investigating social entrepreneurship: A multidimensional model. Journal of World Business 41, 21-35. 
1 Whitford, D., 2015. Here Comes the Airbnb of the Solar Industry, in: Whitford, D. (Ed.), Inc. Built from Passion. Inc., http://www.inc.com/david-whitford/built-from-passion-yeloha.html.

Wilson, F., Post, J., 2013. Business models for people, planet (\& profits): exploring the phenomena of social business, a marketbased approach to social value creation. Small Business Economics 40, 715-737.

Wittneben, B.B., 2012. The impact of the Fukushima nuclear accident on European energy policy. Environmental Science \& Policy $15,1-3$.

Wüstenhagen, R., Boehnke, J., 2008. Business models for sustainable energy. Perspectives on Radical Changes to Sustainable Consumption and Production, Greenleaf Publishing Ltd, Sheffield, 70-80.

Yunus, M., Moingeon, B., Lehmann-Ortega, L., 2010. Building social business models: Lessons from the grameen experience. Long Range Planning 43, 308-325.

Zott, C., Amit, R., 2010. Business model design: an activity system perspective. Long range planning 43, 216-226.

Zott, C., Amit, R., Massa, L., 2011. The business model: Recent developments and future research. Journal of Management 37 , 1019-1042. 


\section{University Library}

\section{- M M N E R VA A gateway to Melbourne's research publications}

Minerva Access is the Institutional Repository of The University of Melbourne

Author/s:

Wainstein, ME;Bumpus, AG

Title:

Business models as drivers of the low carbon power system transition: a multi-level perspective

Date:

2016-07-10

Citation:

Wainstein, M. E. \& Bumpus, A. G. (2016). Business models as drivers of the low carbon power system transition: a multi-level perspective. JOURNAL OF CLEANER PRODUCTION, 126, pp.572-585. https://doi.org/10.1016/j.jclepro.2016.02.095.

Persistent Link:

http://hdl.handle.net/11343/91562 